\title{
MUSYKIL I'RAB AL-QURAN AL-KARIM WA GHARIBUHU
}

\author{
Rozaanah \\ Program Studi Pendidikan Bahasa Arab STAI As-Sunnah \\ Jl. Medan-Tj. Morawa, KM 13, Gg. Darmo, Desa Bangun Sari, Kab. D. Serdang, Sumut \\ rozaanah_pro@yahoo.com
}

\begin{abstract}
Abstrak: Musykil i'rab al-quran secara leksikal berarti merupakan kesalahankesalahan perubahan yang terjadi pada akhir kata baik secara lafazh atau taqdirnya pada kalam Allah yang diturunkan kepada Nabi Muhammad saw. Dilihat pada beberapa contoh dari ayat al-quran memang secara zhahirnya seolah-olah terdapat kesalahan di dalam i'rab, seperti kata "washhabiriina" di dalam al-quran surah Al-Baqarah ayat 177 dan kata "'asyarah" di dalam al-quran surah al-Baqarah ayat 196. Namun jika ditelusuri sebenarnya tidak ada terdapat kesalahan i'rab pada ayat al-quran tersebut. Begitupun dengan Gharib al-quran, ialah kata yang sifatnya jauh atau samar dari kepahaman. Gharib al-quran merupakan ilmu al-quran yang membahas mengenai arti kata dari kata-kata yang ganjil dalam al-quran yang tidak biasa digunakan dalam percakapan sehari-hari. Seperti kata "bishshabri" di dalam al-quran surat al-Baqarah ayat 45. Gharib al qur'an terbagi menjadi dua, yaitu; 1) hal yang jauh makananya serta samar, yang hanya dapat dipahami setelah melalui proses pemikiran yang dalam, dan 2) perkataan seseorang yang rumahnya jauh dari kabilah Arab sehingga jika kalimat tersebut diungkapkan kepada kita (orang non Arab) maka otomatis kita langsung menganggapnya aneh.

Adapun hikmah musykil i'rab dan gharib al-quran al-Karim ini adalah mengundang tumbuhnya penalaran ilmiyah, mengambil perhatian umat, dan memperoleh keyakinan terhadap eksistensi al qur'an sebagai kalam Allah.
\end{abstract}

Kata Kunci : Musykil, i’rab, gharib al-quran

\section{A. Pendahuluan}

Al-quran adalah mukjizat Islam yang abadi di mana semakin maju ilmu pengetahuan, semakin tampak validitas kemukjizatannya. Allah swt. menurunkannya kepada Nabi Muhammad saw., demi membebaskan manusia dari berbagai kegelapan hidup menuju cahaya ilahi, dan membimbing mereka ke jalan yang lurus. Rasulullah menyampaikannya kepada para sahabatnya sebagai penduduk asli Arab yang sudah tentu dapat memahami tabiat mereka. Jika terdapat sesuatu yang kurang jelas bagi mereka tentang ayat-ayat yang mereka terima, mereka langsung menanyakannya kepada Rasulullah shallallahu 'alaihi wasallam. 
Al-quran diturunkan berbahasa Arab. Seseorang tidak akan dapat memahami kitab dan sunnah dengan pemahaman yang benar dan selamat (dari penyelewengan) kecuali dengan bahasa Arab. Menyepelekan dan menggampangkan bahasa Arab akan mengakibatkan lemah dalam memahami agama serta jahil (bodoh) terhadap permasalahan agama.

Walaupun bahasa al-quran meski dipahami oleh orang-orang muslim, namun juga banyak orang-orang non muslim mengerti dengan bahasa Arab yang merupakan bahasa al-quran ini, dan banyak mereka yang berpandangan negatif terhadap bahasa Arab Fusha dan masalah i'rab. Disinilah salah satu upaya orang-orang kafir untuk menyerang al-quran, yaitu tuduhan adanya penulisan dan bacaan ayat al-quran yang bertentangan dengan kaedah nahwu dan sharaf. Untuk membuktikan tuduhannya, mereka mengetengahkan beberapa ayat al-quran yang di dalamnya menurut mereka adanya kesalahan i'rab. Padahal pada penulisan dan bacaan yang dianggap aneh dan janggal tersebut telah dibahas dan dikaji oleh para ulama tafsir maupun ulumul Quran.

\section{B. Musykil I'rab al-Quran al-Karim}

\section{Pengertian}

Secara etimologi, musykil i'rab al-quran terdiri dari beberapa kata, yaitu musykil, i'rab, dan al-quran. Kata musykil مشكل berarti (perkara) yang susah, yang samar, yang musykil. ${ }^{1}$ Sedangkan i'rab menurut Ya'qub dan 'Ashi yaitu:

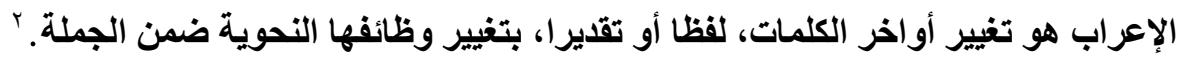

I'rab adalah perubahan yang terjadi pada akhir kata, baik secara lafazh atau taqdirnya, dengan perubahan fungsi/kedudukannya di dalam kalimat.

Pendapat Muhammad Sirhaan yang dimaksud dengan i'rab adalah perubahan bunyi akhir setiap kata berdasar kedudukannya dalam suatu kalimat, atau dengan kata lain yang lebih konkrit adalah apakah akhir kata itu suku hidup ataukah suku mati, atau harus dengan tanda lain seperti

\footnotetext{
${ }^{1}$ Mahmud Yunus, Kamus Arab-Indonesia, (Jakarta: Yayasan Penyelenggara Penterjemah/ Pentafsir al-Qur'an, 1973), h. 202.

${ }^{2}$ Emil Badi' Ya'qub dan Mesyal 'Ashi, al-Mu'jam al-Mufasshal fi al-Lughah wa al-Adab, (Beirut: Dar al-Ilmi li al-Malayin, 1987), h. 168.
} 
penghilangan huruf berdasarkann perbedaan kata fungsi yang mendahuluinya ataupun berdasarkan perbedaan fungsi kata itu dalam kalimat. ${ }^{3}$

al-quran adalah Kalam Allah yang diturunkan kepada Nabi Muhammmad saw., beribadah jika membacanya. ${ }^{4}$ Dan ilmu i'rab al-quran adalah Ilmu yang menerangkan baris Al Qur-an dan kedudukan lafadz dalam kalimat. ${ }^{5}$

Jadi musykil i'rab al-quran adalah kesalahan-kesalahan perubahan yang terjadi pada akhir kata baik lafazh atau taqdirnya pada kalam Allah yang diturunkan kepada Nabi Muhammad saw.

2. Contoh Musykil di dalam al-Quran al-Karim

a. QS. Al-Baqarah: 177

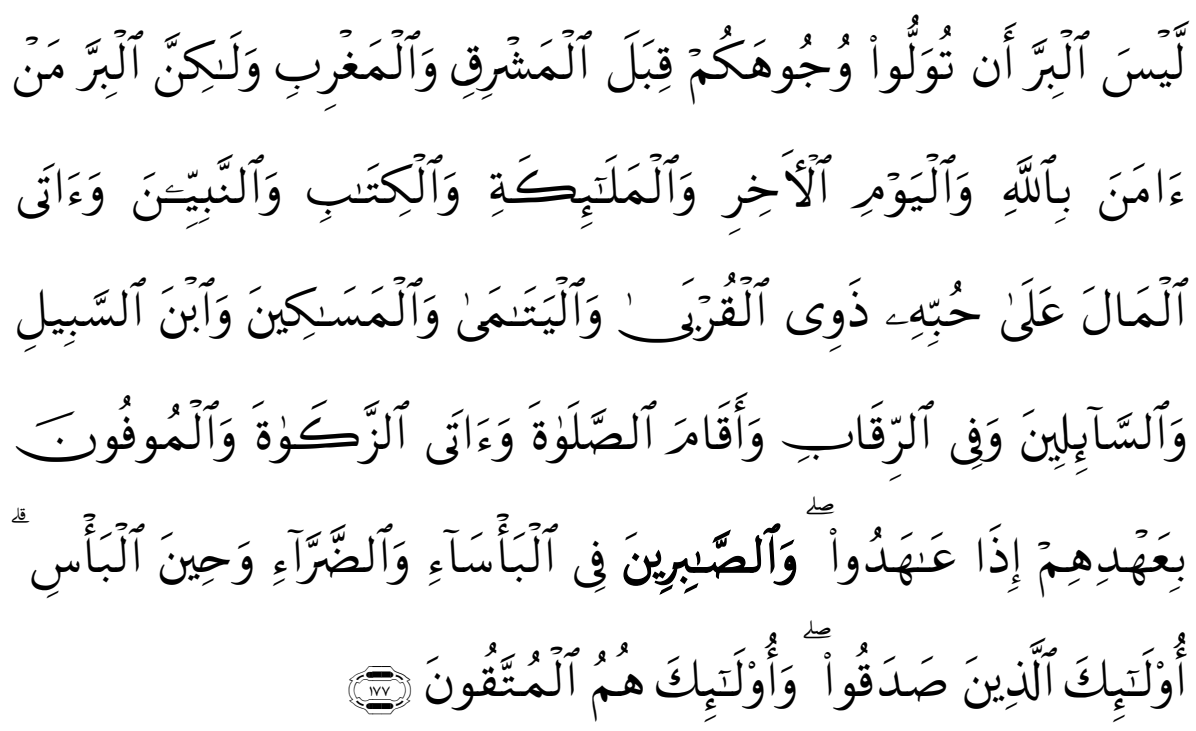

"bukanlah menghadapkan wajahmu ke arah timur dan barat itu suatu kebajikan, akan tetapi Sesungguhnya kebajikan itu ialah beriman kepada Allah, hari Kemudian, malaikat-malaikat, kitabkitab, nabi-nabi dan memberikan harta yang dicintainya kepada kerabatnya, anak-anak yatim, orang-orang miskin, musafir (yang memerlukan pertolongan) dan orang-orang yang meminta-minta; dan (memerdekakan) hamba sahaya, mendirikan shalat, dan menunaikan

\footnotetext{
3 Muhammad Sirhaan, Fiqhullughah (Ilmu Bahasa Arab), (Yogyakarta: IKIP Semarang Press, 1956 M / 1376 H), h. 67.

4 Manna' al-Qatthan, Mabahits fi Ulum al-Qur'an, (Riyadh: Mansyurat al-'Ashr al-Hadits, 1973), h. 21.
}

${ }^{5}$ http://islamwiki.blogspot.com/2009/02/pembagian-ilmu-al-quran-dan-macamnya.html Jurnal WARAQAT • Volume IV, No. 2, Juli-Desember 2019| 
zakat; dan orang-orang yang menepati janjinya apabila ia berjanji, dan orang-orang yang sabar dalam kesempitan, penderitaan dan dalam peperangan. mereka Itulah orang-orang yang benar (imannya); dan mereka Itulah orang-orang yang bertakwa."

Az-Zanadiqah mengatakan bahwa di sini ada keganjilan i'rab

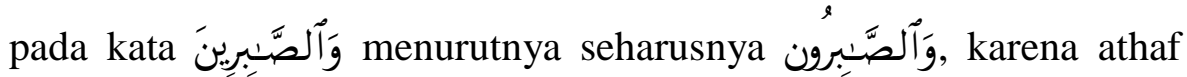
pada kata وَالَْمُوفُوبَ, akan tetapi ini dibantah oleh para ahli tafsir, mereka mengatakan bahwasanya وَألصَّبرِينَ nashab. Sebagaimana pendapat Imam Thabari bahwa وَألصَّدبرِين adalah nashab, dia na'at dari

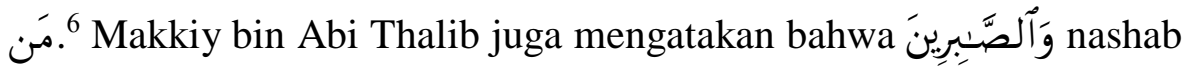

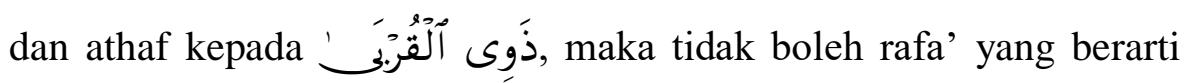

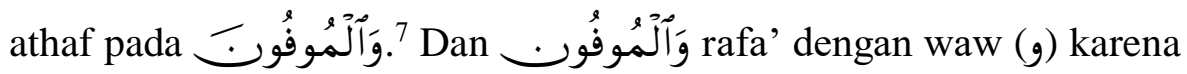
ia adalah isim ma'thuf terhadap مَنَ 8َامَن

b. QS. al-Baqarah : 196

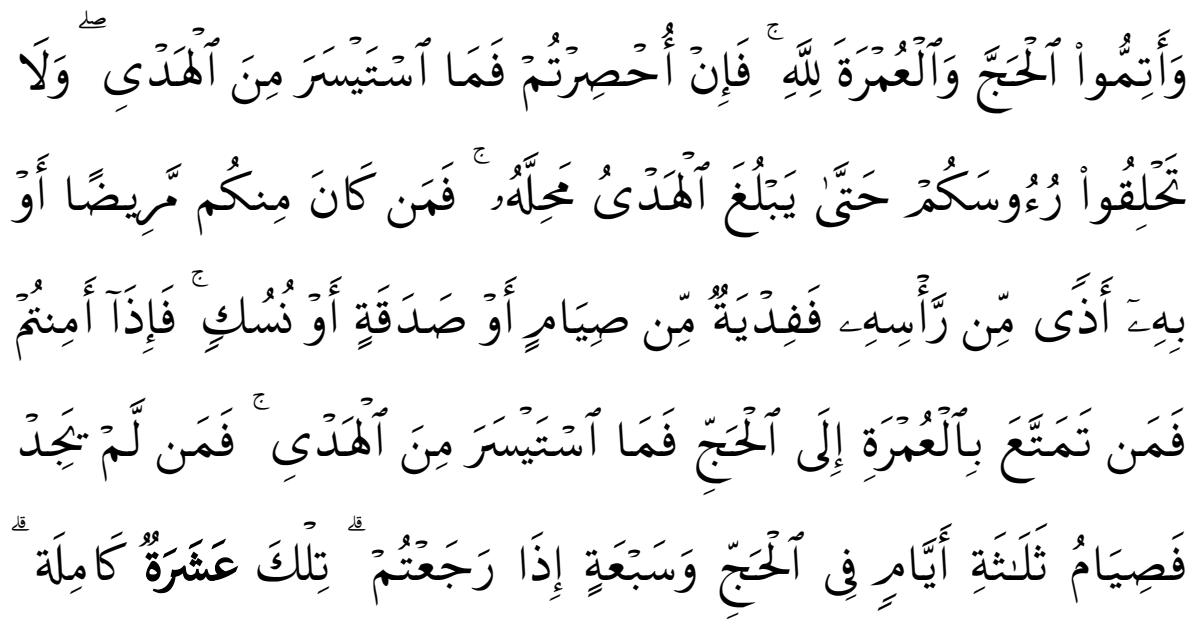

6 Yusuf bin Khalaf bin Mahal al-'Isawi, Radd al-Buhtan 'an I'rab Ayat min al-Qur'an alKarim, (Kairo: Dar Ibn al-Jauzi, 1431 H), h. 59-61.

7 Abi Muhammad Makkiy bin Abi Thalib al-Qaisiy, Musykil I'rab al-Qur'an, (Beirut: Muassasah al-Risalah, 1988 M / 1408 H), h. 188.

8 Bajat Abd al-Wahid Shaleh, al-I'rab al-Mufasshal li Kitab Allah al-Murrattal, j. 1, (t.tp: Dar al-Fikr, t.th), h . 226. 


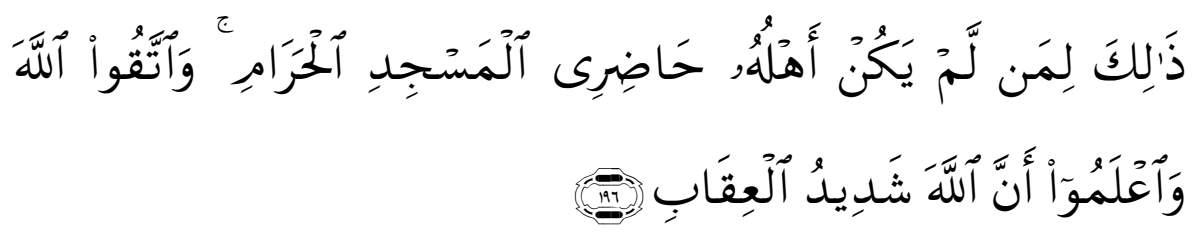

"dan sempurnakanlah ibadah haji dan 'umrah karena Allah. jika kamu terkepung (terhalang oleh musuh atau karena sakit), Maka (sembelihlah) korban yang mudah didapat, dan jangan kamu mencukur kepalamu, sebelum korban sampai di tempat penyembelihannya. jika ada di antaramu yang sakit atau ada gangguan di kepalanya (lalu ia bercukur), Maka wajiblah atasnya berfid-yah, Yaitu: berpuasa atau bersedekah atau berkorban. apabila kamu telah (merasa) aman, Maka bagi siapa yang ingin mengerjakan 'umrah sebelum haji (di dalam bulan haji), (wajiblah ia menyembelih) korban yang mudah didapat. tetapi jika ia tidak menemukan (binatang korban atau tidak mampu), Maka wajib berpuasa tiga hari dalam masa haji dan tujuh hari (lagi) apabila kamu telah pulang kembali. Itulah sepuluh (hari) yang sempurna. demikian itu (kewajiban membayar fidyah) bagi orang-orang yang keluarganya tidak berada (di sekitar) Masjidil Haram (orang-orang yang bukan penduduk kota Mekah). dan bertakwalah kepada Allah dan ketahuilah bahwa Allah sangat keras siksaan-Nya."

Orang-orang yang mengatakan bahwa adanya musykil i'rab di dalam al-quran mengatakan bahwa pada ayat di atas terdapat عَشَشَرَة karena ma'dudnya muannats, dan kaedah 'adad di sini menyalahi aturan. Salah satu mereka mengatakan bahwa تَلكَكَ عَشَرَة كَامِلَة sebenarnya adalah تِلَكَ عَشَرَ كَامِلَ karena ma'dudnya mu'annats, yang

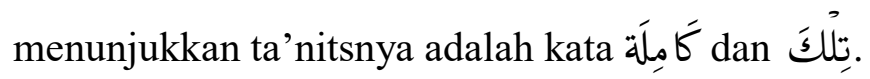

Sebenarnya di sini ada kekeliruan orang-orang yang menganggap adanya musykil i'rab dalam al-quran tentang ma'dudnya yang dikatakan mu'annats, ma'dud yang sebenarnya adalah يوم 'jama أَيَّام 
dan adalah mudzakar. al-Samin al-Hulabiy mengatakan bahwa

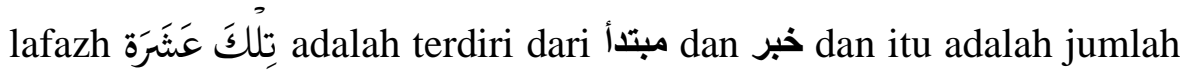

dari 7 dan $3 .^{9}$

Untuk mengatasi kesalahan dalam mengi'rab, maka yang harus diperhatikan di antaranya adalah :

1. Memahami makna ayat yang hendak dii'rab, apakah lafaz tersebut mufrad atau murakkab.

2. Memperhatikan ketepatan gramatika bahasa Arab.

3. Menghindari dari perkara-perkara yang begitu jauh dari aturan yang baku (konvensional), aspek-aspek yang lemah, dan bahasa-bahasa yang menyimpang (al-syadzah), dan mengambil sesuatu yang dekat dengan aturan konvensional, kuat lagi fasih.

4. Hendaklah memperhatikan semua yang dikandung oleh suatu lafazh dari beberapa aspek yang tampak (zhahir).

5. Hendaklah memperhatikan bentuk tulisan (al-rasam).

6. Hendaklah menjauhkan diri dari anggapan bahwa lafazh tambahan dalam al-quran, tidak memiliki makna apa-apa. ${ }^{10}$

\section{Gharib al-Quran al-Karim}

1. Pengertian

Gharib sebagaimana di dalam al-Mu'jam al-Mufasshal fi al-Lughah wa al-Adab yaitu:

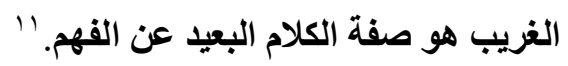

Gharib adalah sifat kalam yang jauh/samar dari kepahaman.

Gharib juga berarti asing atau sulit pengertiannya. Apabila dihubungkan dengan al qur'an maka yang dimaksud adalah ayat-ayat al

\footnotetext{
${ }^{9}$ Yusuf bin Khalaf bin Mahal al-'Isawi, op.cit., h. 63-64.

10 Mohammad Nur Ichwan, Memahami Bahasa al-Qur'an; Refleksi atau Persoalan Linguistik, (Yogyakarta: Pustaka Pelajar, 2002), h. 107-114.

${ }^{11}$ Emil Badi' Ya'qub dan Mesyal 'Ashi, op.cit., h. 901.
} 
qur'an yang sukar pemahamannya sehingga hampir-hampir tidak dapat dimengerti. ${ }^{12}$

Gharib al-quran adalah ilmu al-quran yang membahas mengenai arti kata dari kata-kata yang ganjil dalam al-quran yang tidak biasa digunakan dalam percakapan sehari-hari. ${ }^{13}$

Menurut Abu Sulaiman al Khotthobi : gharib al-quran adalah suatu hal yang samar dan jauh dari kepahaman. Beliau membagi gharib al qur'an menjadi dua ; yang pertama adalah hal yang jauh makananya serta samar, yang hanya dapat dipahami setelah melalui proses pemikiran yang dalam. Yang kedua adalah perkataan seseorang yang rumahnya jauh dari kabilah arab sehingga jika kalimat tersebut diungkapkan kepada kita (orang arab) maka otomatis kita langsung menganggapnya aneh. ${ }^{14}$

Jadi gharib al-quran adalah sifat kalam yang jauh/samar dari kepahaman yang terdapat di dalam ayat al-quran.

\section{Contoh}

a. lafazh al-Itsm

Lafazh al-itsm dilihat pada bentuk jama'nya adalah آثنام, Atsam dan Atsâm adalah isim masdar dari kata kerja atsima-ya'tsamu, yang berarti perbuatan yang mengakhirkan atau menjauhkan dari pahala. Maknanya yang mengandung arti البطء. Pada al-quran surat al-

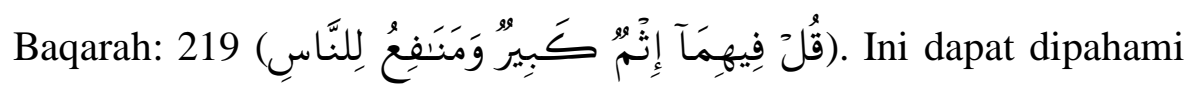
bahwa الإثم bermakna menjauhkan dari kebaikan (إبطاء عن خيرات). الكنب juga dinamai dengan, karena didapati suatu hal dalam lafazh الإثم yang masih termasuk ke dalam makna lafazh, seperti lafazh حيوان yang juga dapat disebut sebagai الإنسان, karena ada beberapa sifat manusia yang serupa dengan hewan. Salah satu

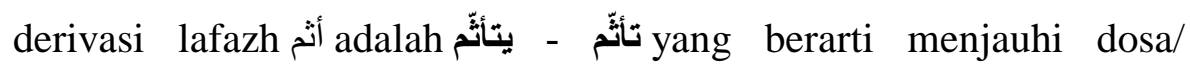

\footnotetext{
${ }^{12}$ Nashruddin Baidan, Wawasan Baru Ilmu Tafsir, Cet. I ; Yogyakarta: Pustaka Pelajar, 2005, h. 267

${ }^{13}$ Hamzah, Muchotob, Studi Al-Qur'an Komprehensif, ( Yogyakarta: Gama Media, 2003).

${ }^{14} \mathrm{http} / / /$ hijausegarsaja.blogspot.com/2011/01/ghoribul-quran.html Jurnal WARAQAT • Volume IV, No. 2, Juli-Desember 2019| 
kesalahan, seperti lafazh تحوّب yang berarti menjauhi atau memperkecil perbuatan dosa.

Selain itu الإِّم bermakna dosa. Seperti dalam firman Allah Q.S.

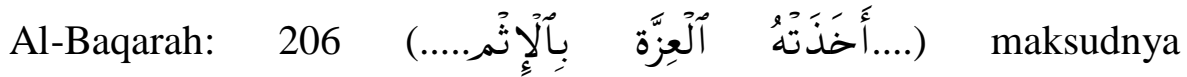
kesombongannya bangkit dan menyebabkannya berbuat dosa. Dan الآثم yang berarti orang yang berdosa. Hal ini terungkap dalam firman

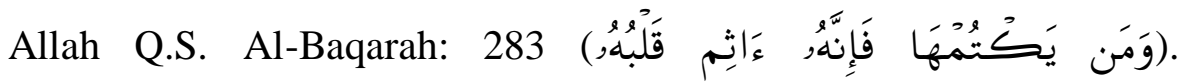
Lafazh الإثم pada ayat ini diperbandingkan dengan lafazh البر , sebagaimana yang dikatakan oleh Rasulullah: "Al-Birr adalah suatu hal yang menentramkan jiwa, sedang al-itsm adalah suatu hal yang menekan atau mengekang jiwa."

Firman Allah dalam Q.S. AL-Muthaffifin ayat 12 yang berbunyi

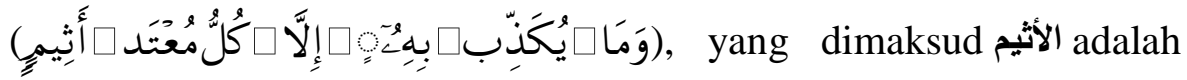
الآثث, yang berarti orang yang berdosa atau bersalah.

Selain diartikan sebagai dosa atau kesalahan, lafazh al-itsm juga memilki pilihan makna lain. Firman Allah dalam Q.S. A-Furqan: 68 dalam ayat ini bermakna siksa (العذاب dikatakan dapat menjadi siksa disaat seseorang mengerjakan dosa, mulai dosa kecil hingga dosa besar. ${ }^{15}$

b. Lafazh al-Shabr

Di dalam QS. Surat al-Baqarah ayat 45

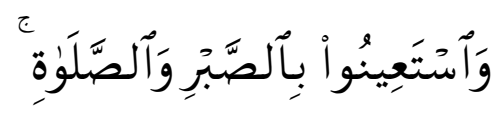

Ibnu Qutaibah dan sebagian mufassir mengatakan bahwa الصَّبَرْ

berarti puasa. Mujahid mengatakan untuk bulan ramadhan berarti

15 Al-Raghib al-Asfahani, Mu'ajim Mufradat alfazh al-Qur'an, (Libanon: Dar al-Kutub alIlmiah, 2008), h. 21-22. 
bulan kesabaran, dan orang yang berpuasa memiliki kesabaran untuk dirinya dari makan dan minum. Asal kata sabar adalah memenjarakan, dinamakan puasa dengan istilah sabar karena memenjarakan diri dari makan, minum, dan nikah.

Adapun kata أَصْبر pada QS. al-Baqarah ayat 175

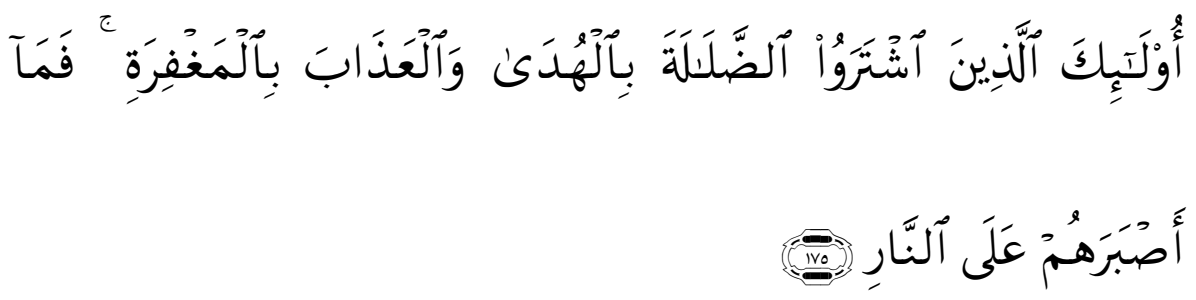

Di sini berarti pekerjaan yang mereka lakukan adalah pekerjaan untuk menentang / menuju neraka. ${ }^{16}$

\section{Faedah Musykil I'rab dan Gharib dalam al-quran al-Karim}

Dari penjelasan di atas dapatlah kita mengambil hikmah dan mengetahui faedahnya, diantaranya adalah:

1. Mengundang tumbuhnya penalaran ilmiyyah, artinya memahami ayat yang sulit pemahamannya akan melahirkan berbagi usaha untuk memecahkannya dengan cara memperhatikan pemakaiannya dalam bahasa arab seperti syair dan sebagainya. Dalam hal ini tentu banyak membutuhkan pemikiran yang rasional dari pada emosional.

2. Mengambil perhatian umat, artinya sesuatu yang asing, aneh dan tidak seperti biasanya akan selalu menjadi pusat perhatian. Seseorang akan merasa penasaran dan ingin mengetahuinya, sebab manusia diciptakan dengan tabiat senang terhadap hal-hal yang baru. Ini adalah salah satu cara berdakwah, setelah tertarik maka dimaksukkan tujuan bedakwah itu sendiri.

3. Memperoleh keyakinan terhadap eksistensi al qur'an sebagai kalam Allah. Dengan diketahui maksud yang terkandung dalam ayat-ayat musykil i’rab

16 Muhammad al-Tuanji, al-Mu'jam al-Mufasshal fi Tafsir al-Gharib al-Qur'an al-Karim, (Libanon: Dar al-Kutub al-Ilm iah, 2003 M / 1424 H), h. 273-274. 
dan gharib, maka akan diperoleh suatu pemahaman yang mendalam dan terasa betapa tingginya bahasa yang dibawa oleh al qur'an, baik lafazh maupun maknanya.

Dengan demikian diketahui bahwa al qur'an bukanlah dari makhluk Allah, melainkan dzat yang menciptakannya.

\section{Simpulan}

Dapat penulis simpulkan bahwa musykil i'rab al-quran bukan berarti di dalam al-quran terdapat kesalahan-kesalahan dalam kaedah nahw, atau di dalam i'rabnya. Hanya saja ada di antara orang yang menentang bahwa pada al'qur'an itu terdapat kesalahan i'rab yang tidak menemukan kaedahnya secara tepat. Begitupun dengan gharib al-quran. Ini bukan berarti kata yang aneh, tapi kata yang sifatnya jauh atau samar dari kepahaman.

\section{Pustaka Acuan}

al-Asfahani, M. Abu al-Qasim al-Husain bin Muhammad bin al-Mufaddhal alRaghib, Mu'ajim Mufradat alfazh al-quran, Libanon: Dar al-Kutub alIlmiah, 2008.

Baidan, Nashruddin, Wawasan Baru Ilmu Tafsir, Cet. I ; Yogyakarta: Pustaka Pelajar, 2005.

Ichwan, Mohammad Nur, Memahami Bahasa al-quran; Refleksi atau Persoalan Linguistik, Yogyakarta: Pustaka Pelajar, 2002.

al-'Isawi, Yusuf bin Khalaf bin Mahal, Radd al-Buhtan 'an I'rab Ayat min alquran al-Karim, Kairo: Dar Ibn al-Jauzi, $1431 \mathrm{H}$.

Muchotob, Hamzah, Studi Al-quran Komprehensif, Yogyakarta: Gama Media, 2003.

al-Qaisiy, Abi Muhammad Makkiy bin Abi Thalib, Musykil I'rab al-quran, Beirut: Muassasah al-Risalah, $1988 \mathrm{M} / 1408 \mathrm{H}$.

al-Qatthan, Manna', Mabahits fi Ulum al-quran, Riyadh: Mansyurat al-'Ashr alHadits, 1973.

Shaleh, Bajat Abd al-Wahid, al-I'rab al-Mufasshal li Kitab Allah al-Murrattal, j. 1, t.tp: Dar al-Fikr, t.th.

Sirhaan, Muhammad, Fiqhullughah (Ilmu Bahasa Arab), Yogyakarta: IKIP Semarang Press, 1956 M / 1376 H.

al-Tuanji, Muhammad, al-Mu'jam al-Mufasshal fi Tafsir al-Gharib al-quran alKarim, Libanon: Dar al-Kutub al-Ilm iah, 2003 M / 1424 H.

Ya'qub, Emil Badi', dan Mesyal 'Ashi, al-Mu'jam al-Mufasshal fi al-Lughah wa al-Adab, Beirut: Dar al-Ilmi li al-Malayin, 1987.

Yunus, Mahmud, Kamus Arab-Indonesia, Jakarta: Yayasan Penyelenggara Penterjemah/ Pentafsir al-quran, 1973.

http://hijausegarsaja.blogspot.com/2011/01/ghoribul-quran.html

Jurnal WARAQAT Volume IV, No. 2, Juli-Desember 2019| 
http://islamwiki.blogspot.com/2009/02/pembagian-ilmu-al-quran-danmacamnya.html 